\title{
$\left[{ }^{18} \mathrm{~F}\right] \mathrm{CFT}$ synthesis and binding to monoamine transporters in rats
}

\author{
Sarita Forsback ${ }^{1 *}$, Päivi Marjamäki², Olli Eskola', Jörgen Bergman', Johanna Rokka', Tove Grönroos², \\ Merja Haaparanta ${ }^{2}$ and Olof Solin ${ }^{1,3}$
}

\begin{abstract}
Background: We present the electrophilic synthesis of $\left[{ }^{18} \mathrm{~F}\right] 2 \beta$-carbomethoxy-3 $\beta$-(4-fluoro)tropane $\left[\left[^{18} \mathrm{~F}\right] \mathrm{CFT}\right]$ and the pharmacological specificity and selectivity of $\left[{ }^{18} \mathrm{~F}\right] \mathrm{CFT}$ for monoamine transporters in the brain and peripheral organs of rats. The human radiation dose is extrapolated from the animal data.

Methods: $\left[{ }^{18} \mathrm{~F}\right] \mathrm{CFT}$ was synthesized by electrophilic fluorination of a stannylated precursor by using post-targetproduced $\left[{ }^{18} \mathrm{~F}\right] \mathrm{F}_{2}$ as a fluorinating agent. The ex vivo ${ }^{18} \mathrm{~F}$-activity biodistribution of $\left[{ }^{18} \mathrm{~F}\right] \mathrm{CFT}$ in the brain of rats was studied by autoradiography. The binding of $\left[{ }^{18} \mathrm{~F}\right] \mathrm{CFT}$ to the monoamine transporters was studied using in vivo blocking experiments with dopamine transporter [DAT], norepinephrine transporter [NET], or serotonin transporter [SERT] inhibitors. In vivo animal positron emission tomography was used as a comparative method to determine tracer kinetics. Human radiation dose was assessed using OLINDA software.

Results: The radiochemical yield of $\left[{ }^{18} \mathrm{~F}\right] \mathrm{CFT}$ from the initial $\left[{ }^{18} \mathrm{~F}\right] \mathrm{F}^{-}$, decay corrected to the end of bombardment, was $3.2 \pm 1.0 \%$. The specific activity [SA] was $14.5 \pm 3.4 \mathrm{GBq} / \mu \mathrm{mol}$, decay corrected to the end of synthesis. Radiochemical purity exceeded 99\%. DAT-specific binding was found in the striatum, locus coeruleus, and pancreas. NET-specific binding was found in the locus coeruleus. SERT-specific binding was not found in any of the studied organs. Effective dose equivalent [EDE] estimated for the standard human model was $12.8 \mu \mathrm{Sv} / \mathrm{MBq}$. Effective dose [ED] was $9.17 \mu \mathrm{Sv} / \mathrm{MBq}$.

Conclusions: Post-target-produced high-SA $\left[{ }^{18} \mathrm{~F}\right] \mathrm{F}_{2}$ was used to incorporate ${ }^{18} \mathrm{~F}$ directly into the phenyl ring of $\left[{ }^{18} \mathrm{~F}\right]$ CFT. The final product had high radiochemical and chemical purities and a high SA for DAT and NET studies in vivo. In periphery, $\left.{ }^{18} \mathrm{~F}\right] \mathrm{CFT}$ showed a specific uptake in the pancreas. EDE and ED corresponded well with other ${ }^{18} \mathrm{~F}-$ radioligands.
\end{abstract}

Keywords: $\left[{ }^{18} \mathrm{~F}\right] \mathrm{CFT}, \mathrm{DAT}, \mathrm{NET}$, electrophilic fluorination, monoamine transporters

\section{Background}

Dopamine transporters [DAT] are proteins located in the dopaminergic nerve terminals; they regulate the synaptic concentration of dopamine in the brain. Changes in the density and function of DAT in the brain are involved in many neurodegenerative and neuropsychiatric disorders, such as Parkinson's disease and schizophrenia. These changes can be imaged using positron emission tomography [PET].

\footnotetext{
* Correspondence: sarita.forsback@utu.fi

'Radiopharmaceutical Chemistry Laboratory, Turku PET Centre, University of Turku, Porthaninkatu 3, Turku, 20500, Finland

Full list of author information is available at the end of the article
}

Many radioligands, including $\left[{ }^{11} \mathrm{C}\right] \mathrm{CFT}[1]$ and several $\left[{ }^{18} \mathrm{~F}\right] \mathrm{F}$-labeled phenyl tropane analogs of cocaine [2], have been used to study dopamine reuptake in living subjects. However, none of these fulfill the requirements for an optimal radioligand for DAT imaging. $\left[{ }^{11} \mathrm{C}\right] \mathrm{CFT}$ suffers from slow kinetics compared with the short half-life of ${ }^{11} \mathrm{C}$ $\left(T_{1 / 2}=20.4 \mathrm{~min}\right)$. The phenyl tropane analogs have a high or moderate affinity with other monoamine transporters (i.e., serotonin transporters [SERT] and norepinephrine transporters $[\mathrm{NET}])$, or they undergo extensive metabolism. More recently, the new $\left[{ }^{18} \mathrm{~F}\right] \mathrm{F}$-labeled phenyl tropane analog $\left[{ }^{18} \mathrm{~F}\right] \mathrm{FE}-\mathrm{PE} 2 \mathrm{I}$ has shown promise as a radioligand for DAT [3], despite its relatively fast metabolism [4].

\section{空


Previously, electrophilic fluorination of a stannylated precursor, $2 \beta$-carbomethoxy- $3 \beta$-(4-trimethylstannylphenyl)tropane (precursor) to achieve $2 \beta$-carbomethoxy- $3 \beta$ (4- $\left[{ }^{18} \mathrm{~F}\right]$-fluorophenyl)tropane $\left.\left[{ }^{18} \mathrm{~F}\right] \mathrm{CFT}\right]$ (product) (see Figure 1) and preliminary evaluation of the radioligand in rats were reported by Haaparanta et al. [5] and by Bergman et al. [6]. A report on the ability of $\left[{ }^{18} \mathrm{~F}\right] \mathrm{CFT}$ to reflect nigral dopaminergic cell loss in a rat model of Parkinson's disease [7] as well as a study comparing the brain accumulation, metabolism, and kinetics of $\left[{ }^{18} \mathrm{~F}\right]$ CFT and $\left[{ }^{18} \mathrm{~F}\right] \mathrm{CFT}-\mathrm{FP}[8]$ have shown that $\left[{ }^{18} \mathrm{~F}\right] \mathrm{CFT}$ can be used to image DAT in rats. The suitability of $\left[{ }^{18} \mathrm{~F}\right]$ CFT as a radioligand for in vivo studies of DAT in humans has been evaluated [9], and $\left[{ }^{18} \mathrm{~F}\right] \mathrm{CFT}$ has been used in human studies of Parkinson's disease [10-15], schizophrenia [16,17], and detached personality [18]. $\left[{ }^{18} \mathrm{~F}\right] \mathrm{CFT}$ was proven to be a suitable radiotracer to image DAT by PET in humans due to its high target-tonontarget ratio and low metabolism [9] although $\left[{ }^{3} \mathrm{H}\right]$ CFT has also been shown to have some affinity to SERT and NET $[19,20]$. The kinetics of $\left[{ }^{18} \mathrm{~F}\right] \mathrm{CFT}$ are relatively slow, but the half-life of ${ }^{18} \mathrm{~F}\left(T_{1 / 2}=109.8 \mathrm{~min}\right)$ allows equilibrium between specific and nonspecific binding during a human PET study.

A PET radioligand suitable for DAT must have a moderate to high specific activity [SA] to avoid saturation of transporter sites (with associated pharmacological effects) in patients. High SA can be easily achieved by nucleophilic fluorination. The ${ }^{18} \mathrm{~F}$ label is usually incorporated into a molecule via an alkyl side chain, as in the case of $\left[{ }^{18} \mathrm{~F}\right]$ FE-PE2I [3] or [ ${ }^{18} \mathrm{~F}$ ]CFT-FP [21]. However, side chains are often prone to fast metabolism. A more metabolically stable configuration can be achieved by inserting ${ }^{18} \mathrm{~F}$ directly into the phenyl ring via electrophilic fluorination. $\left[{ }^{18} \mathrm{~F}\right] \mathrm{F}_{2}$ is traditionally produced by either ${ }^{20} \mathrm{Ne}(\mathrm{d}, \alpha){ }^{18} \mathrm{~F}$ with an added $\mathrm{F}_{2}$ carrier [22] or ${ }^{18} \mathrm{O}(\mathrm{p}, \mathrm{n})^{18} \mathrm{~F}$ using ${ }^{18} \mathrm{O}_{2} / \mathrm{F}_{2}$ as target [23]. The latter method is more efficient than the former [24]. However, both production methods suffer from low SA. Post-target-produced $\left[{ }^{18} \mathrm{~F}\right] \mathrm{F}_{2}$ has 100- to 1,000-fold higher SA than the traditional methods [25]. Therefore, post-target-produced $\left[{ }^{18} \mathrm{~F}\right] \mathrm{F}_{2}$ offers the possibility of producing high-affinity radioligands through electrophilic labeling.

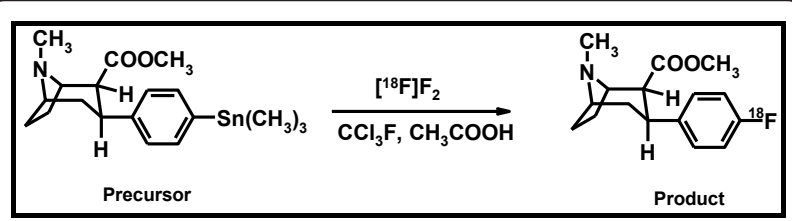

Figure 1 Scheme depicting the use of a stannylated precursor to synthesize $\left[{ }^{18} \mathrm{~F}\right] \mathrm{CFT}$ product.
In the present study, we report the optimized electrophilic synthesis of $\left[{ }^{18} \mathrm{~F}\right] \mathrm{CFT}$ with high SA and its quality assurance for clinical PET studies. The pharmacological specificity and selectivity of $\left[{ }^{18} \mathrm{~F}\right] \mathrm{CFT}$ for monoamine transporters ex vivo are reported. The distribution of ${ }^{18} \mathrm{~F}$ activity in the brain and peripheral organs of rats is reported ex vivo and in vivo in order to compare the methods in the determination of tracer kinetics. The human radiation dose is extrapolated from the animal data using organ level internal dose assessment [OLINDA]/EXM 1.0 software (OLINDA EXM, Vanderbilt University, Nashville, TN, USA) [26].

\section{Methods}

\section{Chemicals and equipment}

The stannylated precursor and the reference compound, $2 \beta$-carbomethoxy-3 $\beta$-(4-fluorophenyl)tropane, were supplied by ABX (ABX GmbH, Radeberg, Germany). All other reagents that were purchased from commercial suppliers were either of synthesis grade or analytical grade and were used without further purification.

Semi-preparative high-performance liquid chromatography [HPLC] was performed using a Merck-Hitachi L-6200 HPLC pump (Merck AG, Darmstadt, Germany) and a Waters $\mu$ Bondapak C18 column $(7.8 \times 300 \mathrm{~mm}$, $10 \mu \mathrm{m}$; Waters Corporation, Milford, MA, USA). A Merck-Hitachi L-7400 UV-absorption detector $(\lambda=215$ $\mathrm{nm})$ and a $2 \times 2$-in NaI crystal for ${ }^{18} \mathrm{~F}$-activity detection were used. The column was eluted with $0.01 \mathrm{M} \mathrm{H}_{3} \mathrm{PO}_{4} /$ $\mathrm{CH}_{3} \mathrm{CN}$ (7:3; flow rate of $3 \mathrm{ml} / \mathrm{min}$ ).

Analytical HPLC was conducted using a Merck-Hitachi L-7100 HPLC pump, an Atlantis dc18 column (5 $\mu \mathrm{m}$; Waters Corporation, Milford, MA, USA), a Merck-Hitachi L-7400 UV-absorption detector $(\lambda=215 \mathrm{~nm})$ and a $2 \times 2$ in $\mathrm{NaI}$ crystal for ${ }^{18} \mathrm{~F}$-activity detection. The eluent used was $0.01 \mathrm{M} \mathrm{H}_{3} \mathrm{PO}_{4} / \mathrm{CH}_{3} \mathrm{CN}$ (75:25; flow rate $1.1 \mathrm{ml} / \mathrm{min}$ ).

Liquid chromatography/mass spectrometry [LC/MS] was performed with a PE SCIEX API 150 EX mass spectrometer (PerkinElmer SCIEX, Toronto, Canada) equipped with a turbo ion-spray source, a PerkinElmer series 200 micro pump (PerkinElmer Instruments, Branford, CT, USA), and a Waters Symmetry C18 column $(2.1 \times 30 \mathrm{~mm}$, $3.5 \mu \mathrm{m}$; Waters Corporation, Milford, MA, USA) were used to measure the concentration of CFT. The column was eluted with $\mathrm{MeOH} / 0.2 \% \mathrm{HCOOH}(\mathrm{aq})$ (flow rate $0.1 \mathrm{ml})$. A Supor Acrodisc $(0.2 \mu \mathrm{m}, 13 \mathrm{~mm}$; Pall Corporation, NY, USA) sterile filter was used to formulate $\left[{ }^{18} \mathrm{~F}\right]$ CFT for injection.

\section{Production of $\left[{ }^{18} \mathrm{~F}\right] \mathrm{F}$}

$\left[{ }^{18} \mathrm{~F}\right] \mathrm{F}^{-}$was obtained via the nuclear reaction ${ }^{18} \mathrm{O}(\mathrm{p}, \mathrm{n}){ }^{18} \mathrm{~F}$ by irradiating $700 \mu \mathrm{l}^{18} \mathrm{O}$-enriched water with a $17-\mathrm{MeV}$ proton beam produced by an MGC-20 cyclotron (Efremov 
Institute of Electrophysical Apparatuses, St Petersburg, Russia).

\section{Production of $\left[{ }^{18} \mathrm{~F}\right] \mathrm{F}_{2}$}

$\left[{ }^{18} \mathrm{~F}\right] \mathrm{F}_{2}$ was synthesized in an electrical discharge chamber by the ${ }^{18} \mathrm{~F} /{ }^{19} \mathrm{~F}$ exchange reaction. The ${ }^{18} \mathrm{~F}$ source was $\left[{ }^{18}\right.$ F]fluoromethane, which was mixed with a low amount (290 to $400 \mathrm{nmol}$ ) of carrier fluorine in neon $\left(\mathrm{Ne} / 0.5 \% \mathrm{~F}_{2}\right)$ inside the discharge chamber. $\left[{ }^{18} \mathrm{~F}\right]$ Fluoromethane was produced from methyl iodide by a nucleophilic substitution reaction with a $\left[{ }^{18} \mathrm{~F}\right] \mathrm{F}^{-} /$Kryptofix K2.2.2 complex in acetonitrile. A detailed description of the $\left[{ }^{18} \mathrm{~F}\right] \mathrm{F}_{2}$ synthesis is presented elsewhere $[25]$.

\section{Synthesis of $\left[{ }^{18} \mathrm{~F}\right] \mathrm{CFT}$}

The stannylated precursor (precursor, 250 to $500 \mu \mathrm{g}, 0.6$ to $1.2 \mu \mathrm{mol}$ ) was dissolved in a mixture of trichlorofluoromethane (Freon-11, $600 \mu \mathrm{l}$ ) and dry acetic acid $(100 \mu \mathrm{l}) .\left[{ }^{18} \mathrm{~F}\right] \mathrm{F}_{2}$ was bubbled through this mixture at room temperature. Freon-11 was evaporated using neon flow, and $600 \mu \mathrm{l}$ of preparative HPLC eluent was added to the residue. With no further modifications, this solution was then loaded onto the preparative HPLC column.

$\left[{ }^{18} \mathrm{~F}\right] \mathrm{CFT}$ was purified by semi-preparative HPLC using the system described in the 'Chemicals and equipment' section. The $3-\mathrm{ml}$ fraction containing the $\left[{ }^{18} \mathrm{~F}\right]$ CFT was collected (Figure 2). The fraction was evaporated to dryness with a vacuum evaporator, formulated into a $0.9 \% \mathrm{NaCl} / 0.1 \mathrm{M}$ phosphate buffer (phosphate buffer $\mathrm{pH} 7,3: 2, v / v)$, and passed through the sterile filter into the end product vial.

\section{Quality of $\left[{ }^{18} \mathrm{~F}\right] \mathrm{CFT}$}

The ${ }^{18} \mathrm{~F}$ activity, $\mathrm{pH}$, and volume were measured from the end product. A sample from the end product was evaluated by the analytical HPLC system described in the 'Chemicals and equipment' section. Determinations of chemical purity, radiochemical purity $[\mathrm{RCP}]$, and SA were conducted by comparing HPLC retention times and peak intensities with a reference compound of known concentration and ${ }^{18} \mathrm{~F}$-activity concentration. Radiochemical yields $[\mathrm{RCY}]$ were calculated from the initial amount of $\left[{ }^{18} \mathrm{~F}\right] \mathrm{F}^{-}$and decay corrected to the end of bombardment [EOB]. The SA of the product was decay corrected to the end of the semi-preparative HPLC separation [EOS].

The SA of the final product was also determined with LC/MS by measuring the $\left[{ }^{19} \mathrm{~F}\right] \mathrm{CFT}$ mass concentration using the same reference as was used with analytical HPLC. The analyses were performed in positive selected ion monitoring mode for $m / z=278$ (corresponding to the protonated molecule $\left[\mathrm{MH}^{+}\right]$of $\left.\left[{ }^{19} \mathrm{~F}\right] \mathrm{CFT}\right)$, and the SAs are decay corrected to the EOS.

\section{Animals}

Sprague-Dawley rats (Harlan Sprague-Dawley, Indianapolis, IN, USA) weighing $251 \pm 59 \mathrm{~g}$ (15 females, 20 males) were used in this study. The rats were housed under standard conditions (temperature $21^{\circ} \mathrm{C}$; relative humidity $55 \pm$ 5\%; 12-h light/dark cycle) with free access to tap water and standard food. Animal care was in accordance with the guidelines of the International Council of Laboratory Animal Science. The Turku University ethics committee for animal experiments and the Animal Experiment Board of the Province of Southern Finland approved this study.

\section{Biodistribution studies}

$\left[{ }^{18} \mathrm{~F}\right] \mathrm{CFT}$ in $0.9 \% \mathrm{NaCl} / 0.1 \mathrm{M}$ phosphate buffer $(3: 2, v / v$, $\mathrm{pH}$ 7) was injected into the tail vein of rats that are sedated with $\mathrm{CO}_{2} / \mathrm{O}_{2}$ (50:50 vol.\%). The ${ }^{18} \mathrm{~F}$ activity injected via $\left[{ }^{18} \mathrm{~F}\right] \mathrm{CFT}$ per rat was $57 \pm 24 \mathrm{MBq}$ (range, 12 to $181 \mathrm{MBq}$ ). This corresponds to a $23 \pm 10-\mathrm{nmol} / \mathrm{kg}$ (5 to $40 \mathrm{nmol} / \mathrm{kg}$ ) administration of CFT, as calculated from the SA that was determined using the HPLC method at the time of injection. The animals were killed in a $\mathrm{CO}_{2}$ chamber at $10 \mathrm{~min}(n=2), 20 \mathrm{~min}(n=3), 40 \mathrm{~min}(n=6)$, or $120 \min (n=3)$ after injection of the tracer. The brains were rapidly removed, and a piece from the cerebellar cortex of each brain was dissected, measured for ${ }^{18} \mathrm{~F}$ activity in a calibrated $3 \times 3$-in $\mathrm{NaI}(\mathrm{Tl})$ well counter (Bicron, Newbury, $\mathrm{OH}, \mathrm{USA}$ ), and weighed. After decay correction, these data, expressed as the percentage of injected dose per gram of tissue $[\% \mathrm{ID} / \mathrm{g}]$, were used to calibrate the absolute uptake of ${ }^{18} \mathrm{~F}$ activity in autoradiographic brain images. The rest of the brain was frozen in isopentane, chilled with dry ice for sectioning with a cryomicrotome, and handled as described in the 'Digital autoradiography' section.

Other organs and tissue samples were rapidly dissected, weighed, and measured for ${ }^{18} \mathrm{~F}$ activity. The decay-corrected uptake of ${ }^{18} \mathrm{~F}$ activity in the organs and tissues was expressed as \%ID/g.

\section{Pharmacological studies}

The specificity of $\left[{ }^{18} \mathrm{~F}\right] \mathrm{CFT}$ binding to DAT in the brain in pretreated rats was assessed with a selective DAT antagonist, GBR12909 (5 mg/kg, Sigma-RBI, St. Louis, MO, USA). Selectivity was examined by injecting rats with a 5$\mathrm{mg} / \mathrm{kg}$ dose of fluoxetine, a selective antagonist for SERT (Sigma-RBI, St. Louis, MO, USA), or with a $5-\mathrm{mg} / \mathrm{kg}$ dose of nisoxetine, a selective antagonist for NET (RBI, Natick, MA, USA). Binding profiles of the antagonists are presented in Table 1. GBR12909, fluoxetine, or nisoxetine dissolved in distilled $\mathrm{H}_{2} \mathrm{O} / 0.9 \% \mathrm{NaCl}(50: 50, v / v, 2 \mathrm{mg} / \mathrm{ml})$ were injected intravenously into rats $60 \mathrm{~min}$ prior to the injection of $\left[{ }^{18} \mathrm{~F}\right] \mathrm{CFT}$. The rats were killed by $\mathrm{CO}_{2}$ inhalation 40 min after injection of $\left[{ }^{18} \mathrm{~F}\right] \mathrm{CFT}$. The brains and organs were handled as in the biodistribution studies. The 


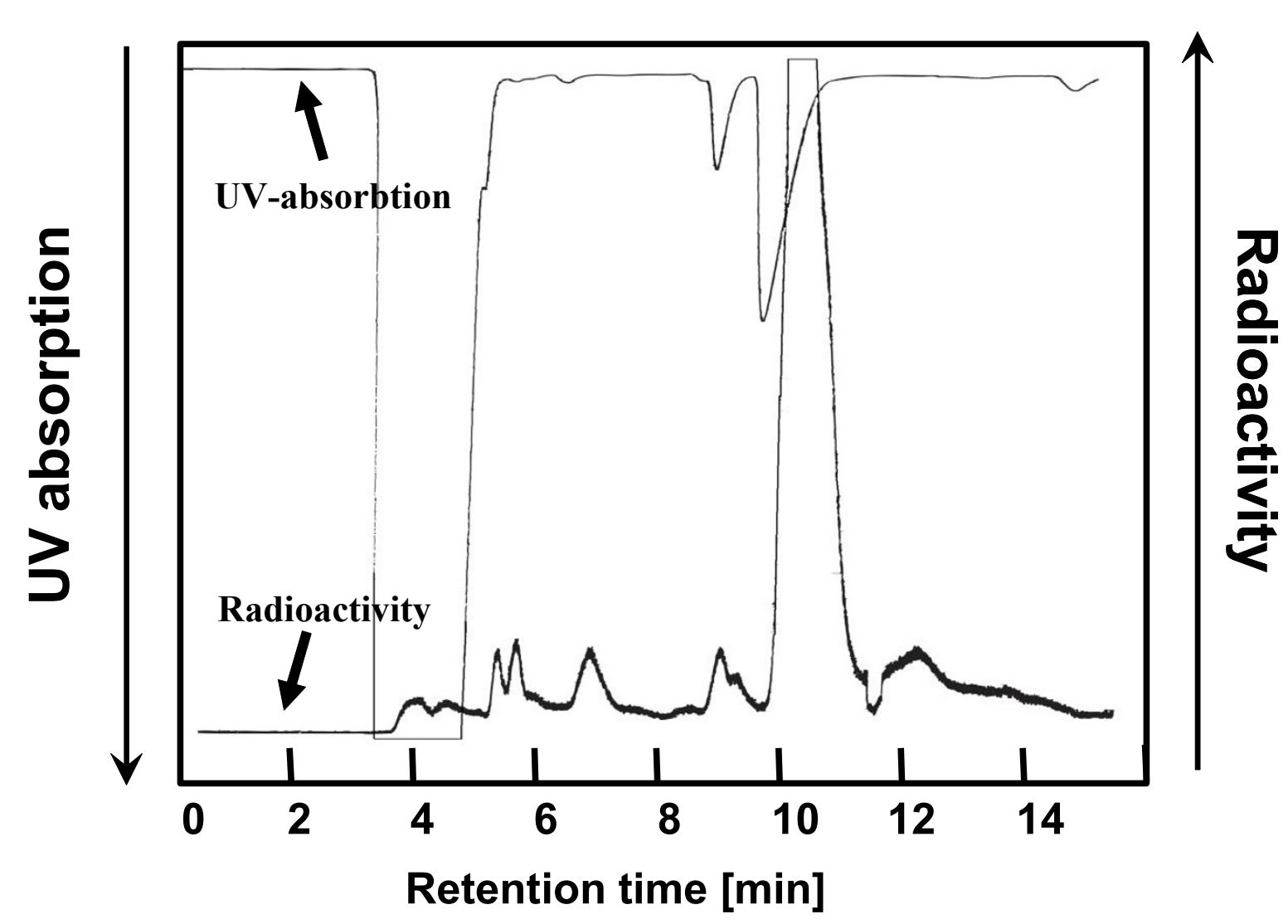

Figure 2 Sample chromatogram of a semi-preparative HPLC separation of $\left[{ }^{18} \mathrm{~F}\right] \mathrm{CFT}$ from the reaction mixture

regional distribution of ${ }^{18} \mathrm{~F}$ activity in the brains of control rats $(n=6)$ and in the brains of rats that were pretreated with GBR12909 $(n=7)$, fluoxetine $(n=6)$, or nisoxetine $(n=6)$ were determined using digital autoradiography.

\section{Digital autoradiography}

Coronal brain sections $(20 \mu \mathrm{m})$ were thaw-mounted onto microscope slides, air dried, and apposed to an imaging plate (Fuji Imaging Plate BAS-TR2025, Fuji Photo Film Co., Ltd., Minato-ku, Tokyo, Japan) for $4 \mathrm{~h}$.

Table 1 Binding profiles of the monoamine transporter antagonist used in this study

\begin{tabular}{lccc}
\hline Antagonist & DAT & SERT & NET \\
\hline CFT [37] & $22.9 \pm 0.4$ & $100 \pm 13$ & $38.6 \pm 9.9$ \\
GBR12909 [38] & $10.6 \pm 1.9^{\mathrm{a}}$ & $132 \pm 0^{\mathrm{b}}$ & $496 \pm 22^{\mathrm{c}}$ \\
Fluoxetine [39] & $3600 \pm 100$ & $0.81 \pm 0.02$ & $240 \pm 10$ \\
Nisoxetine [40] & 477 & 383 & 5.1 \\
\hline
\end{tabular}

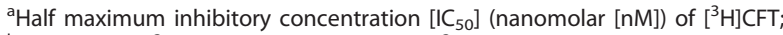
${ }^{b} \mathrm{IC}_{50}(\mathrm{nM})$ of $\left[{ }^{3} \mathrm{H}\right]$ citalopram; ${ }^{\mathrm{C}} \mathrm{IC} \mathrm{C}_{50}(\mathrm{nM})$ of $\left[^{3} \mathrm{H}\right]$ nisoxetine. DAT, dopamine transporter; SERT, serotonin transporter; NET, norepinephrine transporter. Values are $\mathrm{Ki}(\mathrm{nM}) \pm \mathrm{SEM}$, unless otherwise stated.
The imaging plates were scanned with the Fuji Analyzer BAS-5000.

The digital autoradiographic images were analyzed for count density (photo-stimulated luminescence per unit area $\left.\left[\mathrm{PSL} / \mathrm{mm}^{2}\right]\right)$ with a computerized image analysis program (Tina 2.1, Raytest Isotopenmessgeräte, $\mathrm{GmbH}$, Straubenhardt, Germany). Regions of interest [ROIs] were drawn over the frontal cortex, striatum, locus coeruleus, and cerebellum, which were anatomically identified from the cryomicrotome sections using a rat brain atlas [27]. At least 10 sections were analyzed for each brain region, and the count densities for background areas were subtracted from the image data. PSL $/ \mathrm{mm}^{2}$ values were converted into $\% \mathrm{ID} / \mathrm{g}$ values as previously described in the 'Biodistribution studies' section.

\section{PET imaging}

Two PET scans were carried out using an Inveon multimodality PET/computed tomography [CT] (Siemens Medical Solutions, Knoxville, TN, USA) designed for rodents and other small laboratory animals. The device provides 159 transaxial slices, a 10.0-cm transaxial field of view [FOV], and a $12.7-\mathrm{cm}$ axial FOV. Rats were 
anesthetized with $2 \%$ isoflurane approximately $15 \mathrm{~min}$ before measurements. The body temperature of each rat was maintained with a heating pad on which the rat lies. Following the transmission scan for attenuation correction using the CT modality, an emission scan was acquired for $120 \mathrm{~min}$ in three-dimensional [3-D] list mode with an energy window of 350 to $650 \mathrm{keV}$. The scans started immediately after intravenous injection of $\left[{ }^{18} \mathrm{~F}\right] \mathrm{CFT}$ (dose $27.9 \mathrm{MBq}$, mass $830 \mathrm{ng}$, SA $9.3 \mathrm{GBq} /$ $\mu \mathrm{mol}$ and dose $38.0 \mathrm{MBq}$, mass $1,200 \mathrm{ng}$, SA $8.8 \mathrm{GBq} /$ $\mu \mathrm{mol}$ at time of injection, respectively). List mode data were stored in 3-D sinograms, which were then Fourierrebinned into two-dimensional [2-D] sinograms (45 frames with dimensions of $20 \times 15 \mathrm{~s}, 15 \times 600 \mathrm{~s}, 10 \times$ $600 \mathrm{~s})$. The image was reconstructed using 2-D-filtered back projection with a $0.5-\mathrm{mm}$ RAMP filter. ROIs were placed on the striatum, cerebellar cortex, frontal cortex, and liver using the Inveon Research Workplace Image Analysis software (Siemens Medical Solutions USA, Knoxville, TN, USA) and with a CT template as an anatomical reference.

\section{Dosimetry}

The animal \%ID/g tissue data was extrapolated to humans using the percentage kilogram per gram method [28]. In this method, the animal \% ID/g value is first multiplied with the animal's weight and then multiplied with the human organ weight/human weight ratio. Human radiation dose was estimated from these values using OLINDA/EXM 1.0 software [26].

\section{Data analysis and statistical procedures}

Statistical analyses were performed using the SPSS Statistics 17.0 software (SPSS Inc., Chicago, IL, USA). Means were considered significantly different when $p<0.05$. Comparison of SAs was tested using Student's $t$ test (paired, two samples for mean assuming unequal variances).

Effects of the pretreatments were tested using repeated measurement analysis of variance. Results are expressed as means \pm SD for the indicated number of observations.

\section{Results}

\section{Synthesis and quality of $\left[{ }^{18} \mathrm{~F}\right] \mathrm{CFT}$}

Electrophilic fluorination was applied to a stannylated precursor (Figure 1$)$ to synthesize $\left[{ }^{18} \mathrm{~F}\right] \mathrm{CFT}$ product $(n=24)$. The initial $\left[{ }^{18} \mathrm{~F}\right] \mathrm{F}^{-}$activity was $37 \pm 3 \mathrm{GBq}$ (range, 32 to 42 $\mathrm{GBq}$ ), and the average synthesis time was $43 \pm 3 \mathrm{~min}$, including the synthesis of $\left[{ }^{18} \mathrm{~F}\right] \mathrm{F}_{2}$, radiofluorination, and semi-preparative purification. In a semi-preparative HPLC purification, the $\left[{ }^{18} \mathrm{~F}\right] \mathrm{CFT}$ fraction eluting at $10.5 \mathrm{~min}$ was collected (Figure 2). Evaporation to dryness and formulation for injection took an additional $10 \mathrm{~min}$.
The RCY calculated from initial $\left[{ }^{18} \mathrm{~F}\right] \mathrm{F}^{-}$(decay corrected to $\mathrm{EOB})$ was $3.2 \pm 1.0 \%$, and ${ }^{18} \mathrm{~F}$ activity of $\left[{ }^{18} \mathrm{~F}\right]$ CFT was $917 \pm 278 \mathrm{MBq}$ (501 to $1,395 \mathrm{MBq}$ ) at EOS. The SA measured by analytical HPLC was $14.5 \pm 3.4$ $\mathrm{GBq} / \mu \mathrm{mol}$ (8.9 to $23.6 \mathrm{GBq} / \mu \mathrm{mol}$ with all values decay corrected to EOS). From analytical HPLC studies (Figure 3 ), the RCP exceeded $99 \%$ in all cases. The $\mathrm{pH}$ of the final product was 7 . The final product was radiochemically stable for up to $6 \mathrm{~h}$.

From selected batches $(n=19)$, the SA of the final product was determined by LC/MS. The SA of these batches measured by analytical HPLC was $14.9 \pm 3.1 \mathrm{GBq} / \mu \mathrm{mol}$. The SA measured by LC/MS was $18.2 \pm 5.9 \mathrm{GBq} / \mu \mathrm{mol}$. SAs calculated using the analytical HPLC method differed significantly from the SAs calculated using the LC/MS method $(p=0.04)$.

\section{Biodistribution and pharmacological studies}

The ${ }^{18} \mathrm{~F}$-activity accumulation in the striatum, locus coeruleus, frontal cortex, and cerebellum of control rats and monoamine inhibitor-pretreated rats $40 \mathrm{~min}$ after $\left[{ }^{18} \mathrm{~F}\right]$ CFT injection is presented in Table 2. Pretreatment with GBR12909 significantly reduced the $\left[{ }^{18} \mathrm{~F}\right] \mathrm{CFT}$ uptake in the striatum $(p=0.006)$ and locus coeruleus $(p=0.02)$. In nisoxetine-pretreated rats, the $\left[{ }^{18} \mathrm{~F}\right] \mathrm{CFT}$ uptake decreased significantly in the locus coeruleus $(p<0.005)$. Fluoxetine pretreatment had no effect on the accumulation of the ${ }^{18} \mathrm{~F}$ activity in any region studied. Autoradiograms of representative brain sections from a control rat and from rats pretreated with GBR12909, fluoxetine, or nisoxetine are shown in Figure 4.

The region-to-cerebellum ratios at different time points from the ex vivo and in vivo studies are shown in Figure $5 \mathrm{a}, \mathrm{b}$, respectively. In ex vivo studies, the striatum-to-cerebellum ratio increased from $2.1 \pm 0.2$ at $10 \mathrm{~min}$ to $8.8 \pm$ 2.2 at $120 \mathrm{~min}$. The locus coeruleus-to-cerebellum ratio was $2.2 \pm 0.3$ at $10 \mathrm{~min}$ and $3.5 \pm 1.6$ at $120 \mathrm{~min}$. The frontal cortex-to-cerebellum ratio was constant, ranging from 1.4 to 1.6 at all time points and with all pretreatments. All monoamine inhibitors used in this study significantly decreased the locus coeruleus-to-cerebellum ratio. Pretreatment with GBR12909 significantly reduced the striatum-to-cerebellum ratio.

The ${ }^{18} \mathrm{~F}$-activity accumulation in the peripheral organs and tissues after the injection of $\left[{ }^{18} \mathrm{~F}\right] \mathrm{CFT}$ is presented in Table 3. The accumulation of $\left[{ }^{18} \mathrm{~F}\right] \mathrm{CFT}$-derived ${ }^{18} \mathrm{~F}$ activity peaked at $20 \mathrm{~min}$ in most tissues and decreased thereafter (Figure 6). High levels of ${ }^{18} \mathrm{~F}$ activity were recorded in the liver, kidneys, and spleen. In the liver, the highest uptake $(8.3 \pm 1.2 \% \mathrm{ID} / \mathrm{g})$ was measured 120 min after injection of $\left[{ }^{18} \mathrm{~F}\right] \mathrm{CFT} .{ }^{18} \mathrm{~F}$-activity accumulation in the bone increased slowly with time, but it was still low $(0.19 \pm 0.15 \% \mathrm{ID} / \mathrm{g})$ at $120 \mathrm{~min}$. 


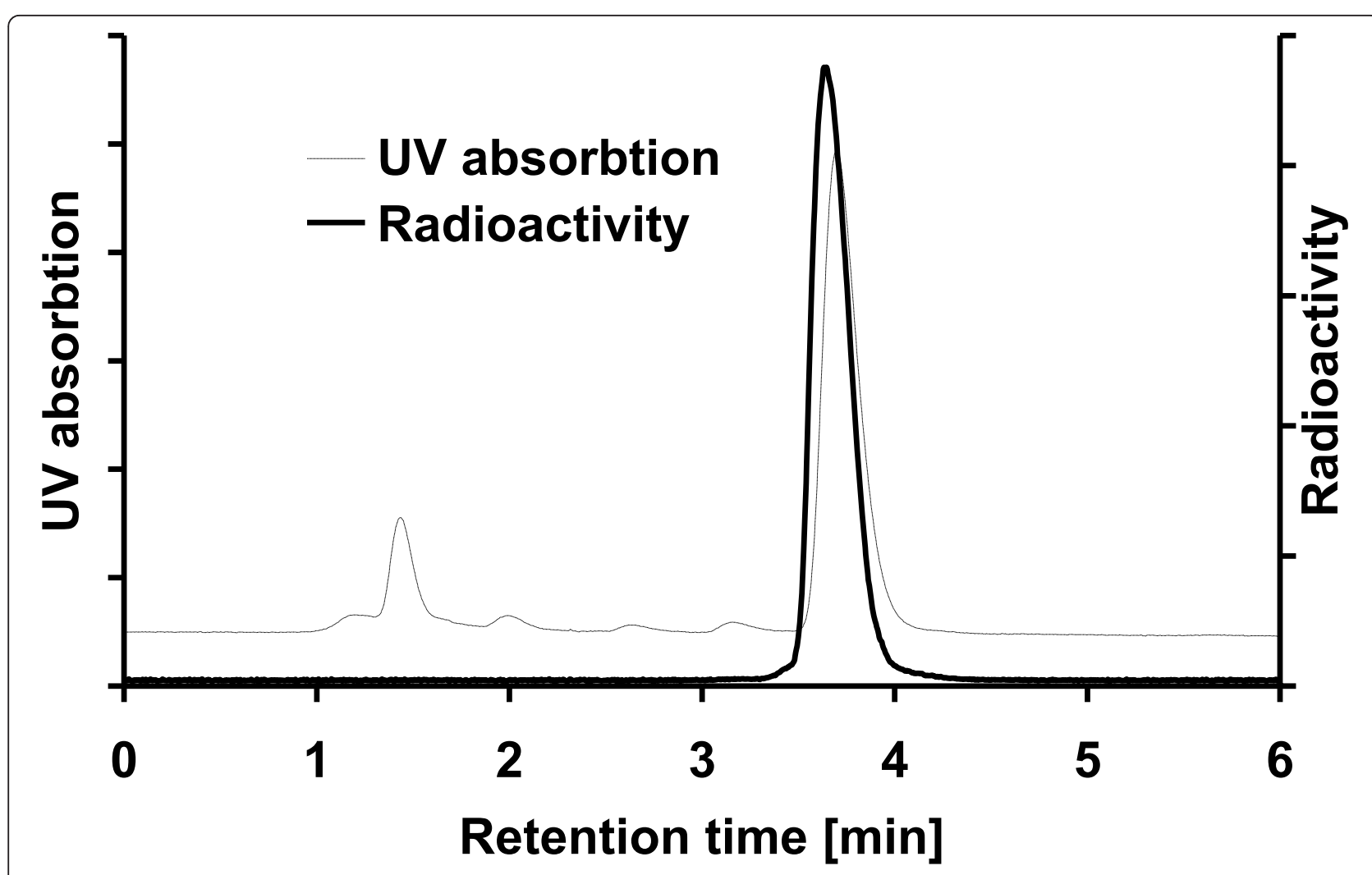

Figure 3 Sample chromatogram of radio-HPLC analysis of formulated $\left[{ }^{18} \mathrm{~F}\right] \mathrm{CFT}$.

Pretreatment of the rats with GBR12909 significantly decreased the uptake of ${ }^{18} \mathrm{~F}$ activity in the pancreas $(p=0.03)$. No significant changes in the ${ }^{18} \mathrm{~F}$-activity uptake were recorded in the periphery of the rats pretreated with nisoxetine or fluoxetine.

\section{PET imaging}

The in vivo distribution and uptake of ${ }^{18} \mathrm{~F}$ activity after $\left[{ }^{18} \mathrm{~F}\right] \mathrm{CFT}$ injection in the brain of rats are presented in Figure 7 . The uptake of ${ }^{18} \mathrm{~F}$ activity in the striatum and cerebellum peaked during the first 5 to $10 \mathrm{~min}$ and decreased thereafter. The striatum-to-cerebellum ratio reached the maximum value of approximately 9 at

Table $2{ }^{18} \mathrm{~F}$-activity uptake $40 \mathrm{~min}$ after injection of $\left[{ }^{18} \mathrm{~F}\right]$ CFT into the brains of control and pretreated rats

\begin{tabular}{lcccc}
\hline Brain region & $\begin{array}{c}\text { Control } \\
\boldsymbol{n}=\mathbf{6}\end{array}$ & $\begin{array}{c}\text { GBR12909 } \\
\boldsymbol{n}=\mathbf{7}\end{array}$ & $\begin{array}{c}\text { Nisoxetine } \\
\boldsymbol{n}=\mathbf{6}\end{array}$ & $\begin{array}{c}\text { Fluoxetine } \\
\boldsymbol{n}=\mathbf{6}\end{array}$ \\
\hline Striatum & $1.55 \pm 0.78$ & $0.49 \pm 0.18^{*}$ & $1.48 \pm 0.22$ & $1.38 \pm 0.75$ \\
Locus coeruleus & $0.67 \pm 0.29$ & $0.37 \pm 0.11^{* *}$ & $0.23 \pm 0.05^{*}$ & $0.47 \pm 0.16$ \\
Frontal cortex & $0.32 \pm 0.08$ & $0.23 \pm 0.04$ & $0.26 \pm 0.03$ & $0.33 \pm 0.13$ \\
Cerebellum & $0.20 \pm 0.04$ & $0.15 \pm 0.04$ & $0.17 \pm 0.02$ & $0.23 \pm 0.09$ \\
\hline
\end{tabular}

${ }^{*} p<0.01$ compared with control;** $p<0.05$ compared with control. Uptake values are in percent injected dose per gram tissue. All values are means \pm SD. The effect of pretreatment was compared with the uptake values of control rats. Means were considered significantly different when $p<0.05$.
$60 \mathrm{~min}$. The time courses of the striatum-to-cortex and cortex-to-cerebellum ratios are shown in Figure 5b. The highest in vivo uptake of ${ }^{18} \mathrm{~F}$ activity in the periphery was observed in the liver. The uptake increased in the liver during the first $60 \mathrm{~min}$ of PET imaging and was almost constant until the end of the scanning (i.e., until 120 min after injection).

\section{Dosimetry}

The effective dose equivalent [EDE] estimated for the standard human model was $12.8 \mu \mathrm{Sv} / \mathrm{MBq}$. Effective dose [ED] was $9.17 \mu \mathrm{Sv} / \mathrm{MBq}$.

\section{Discussion}

Post-target-produced $\left[{ }^{18} \mathrm{~F}\right] \mathrm{F}_{2}$ [25] offers a feasible method to produce PET tracers with high SA for neuroimaging through electrophilic fluorination. When using post-target-produced $\left[{ }^{18} \mathrm{~F}\right] \mathrm{F}_{2}$, the SA depends on several factors, such as the initial amount of $\left[{ }^{18} \mathrm{~F}\right] \mathrm{F}^{-}$and the amount of carrier fluorine used in the ${ }^{19} \mathrm{~F}-{ }^{18} \mathrm{~F}$ exchange reaction [25]. The SA of $\left[{ }^{18} \mathrm{~F}\right] \mathrm{CFT}$ can potentially be increased by further optimizing this ${ }^{19} \mathrm{~F}-{ }^{18} \mathrm{~F}$ exchange reaction by decreasing the amount of carrier $F_{2}$. However, in our hands, this resulted in a dramatic decrease in RCY. The amount of carrier $F_{2}$ used in this study (290 to $400 \mathrm{nmol}$ ) is a compromise, offering SA 


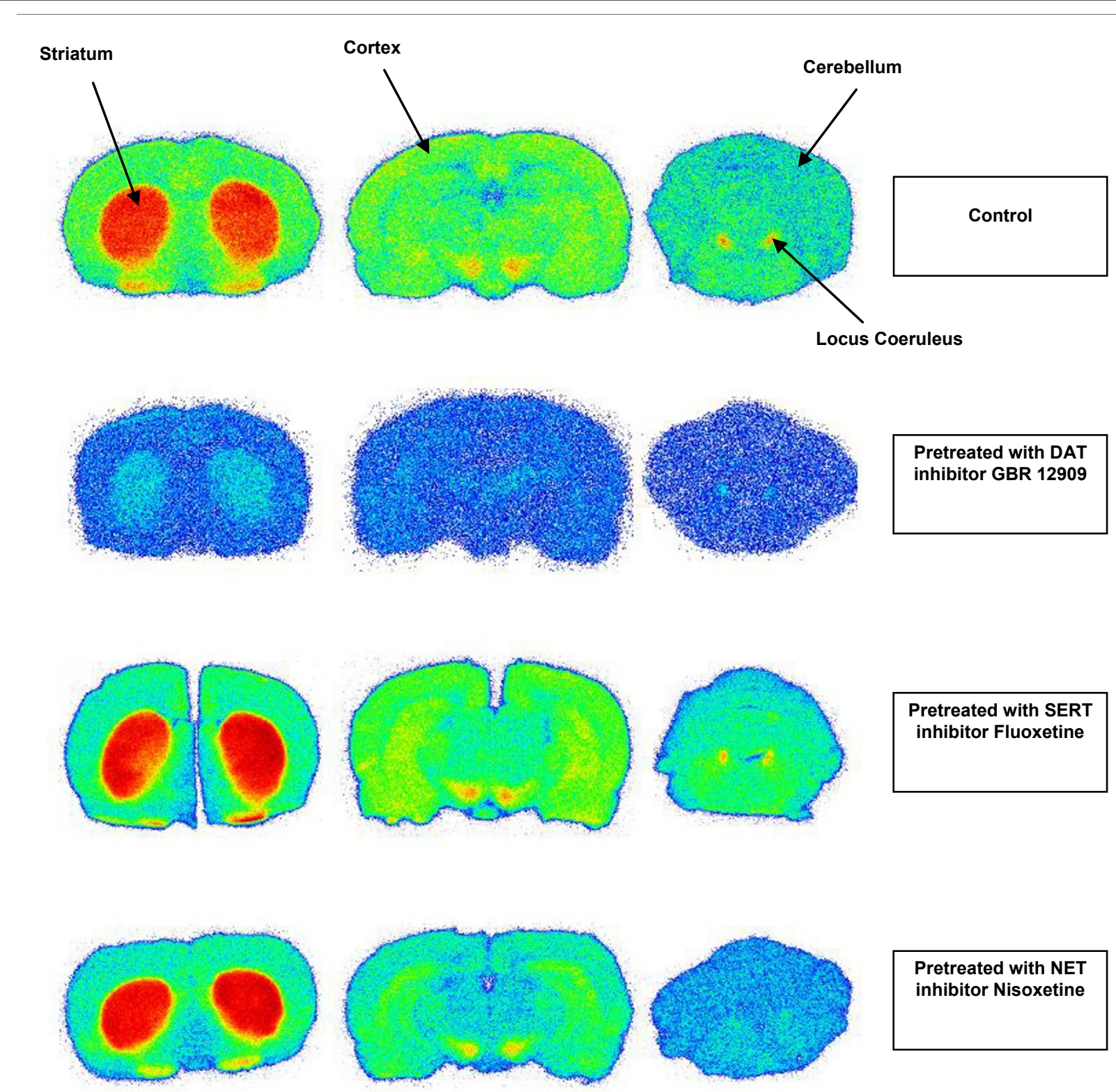

Figure 4 Representative $\left[{ }^{18} \mathrm{~F}\right] \mathrm{CFT}$ autoradiographic images. Brain slices from control rats and from rats pretreated with GBR12909, fluoxetine, or nisoxetine.

and RCY that are high enough for several human PET studies from one production run. The radiochemical and chemical purities of the final product were verified by HPLC, and both were found to fulfill the requirements for human injection (i.e., RCP $>95.0 \%$ and the absence of unknown signals in the UV trace; Figure 3). Signals from compounds other than CFT observed in the UV trace were from the formulation solution.

For radioligands having very high SA, the sensitivity limitation of UV detection means that LC/MS can be the only method to determine the SA [29]. In the present case where $\left[{ }^{18} \mathrm{~F}\right] \mathrm{CFT}$ is synthesized through electrophilic fluorination at high SA, we therefore compared the HPLC/UV absorption and the LC/MS technique for the determination of SA. In quantitative analyses, LC/MS is a faster and more sensitive method than HPLC combined with a UV detector. However, LC/MS is more easily affected by changes in the sample matrix. In this study, the SAs were significantly higher when determined by the LC/MS method than by the HPLC method (i.e., the concentration of CFT was lower when measured by LC/MS than by HPLC). This could 


\section{a}

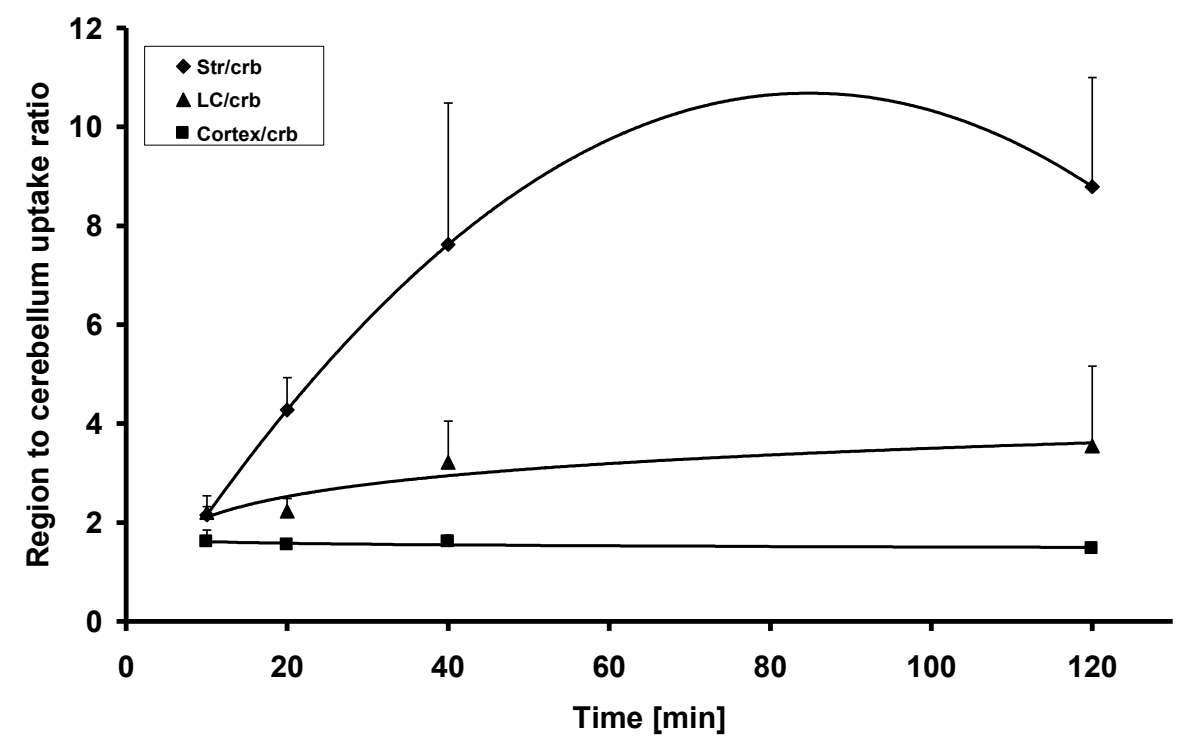

b

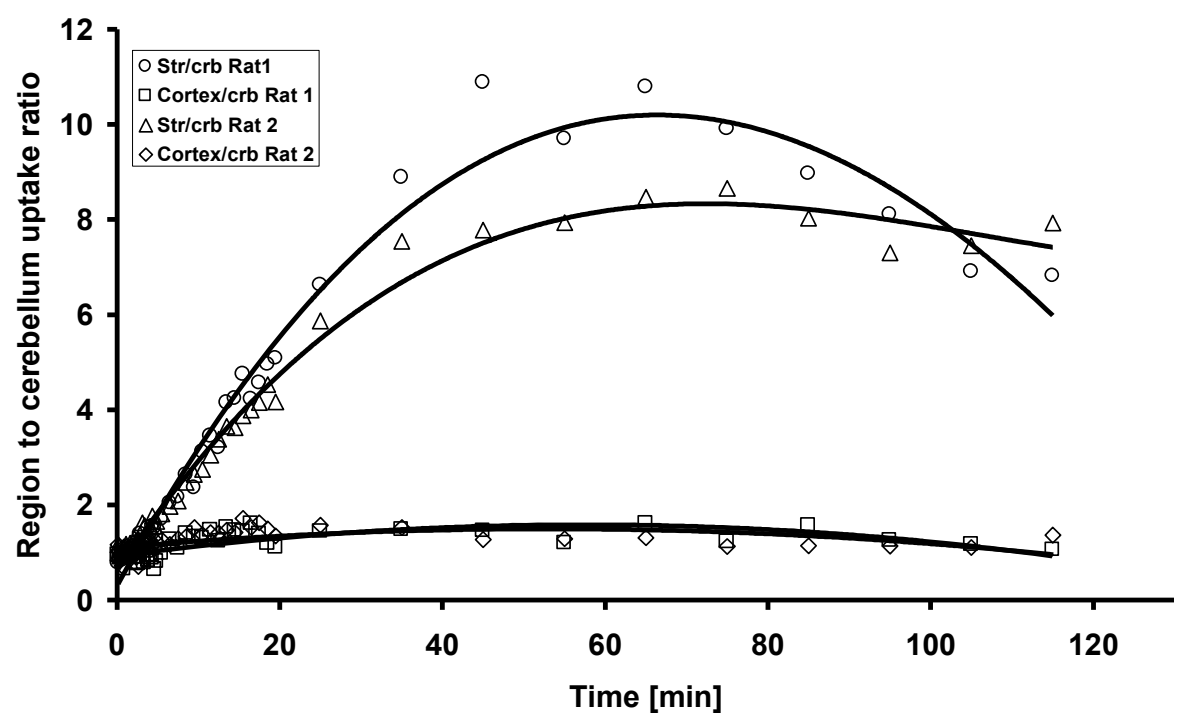

Figure 5 The time courses of the brain region-to-cerebellum ratios. They are from the ex vivo study after $\left[{ }^{18} \mathrm{~F}\right] \mathrm{CFT}$ injection where $n=2$ to 4/time point (a) and from the in vivo animal PET study where $n=2$ (b).

be due to ion suppression in LC/MS [30]. The effect of ion suppression could be diminished by more extensive chromatographic separation or sample preparation prior to MS. However, both methods of analysis are suitable for analysis in the present case.

In the biodistribution study, the highest level of ${ }^{18} \mathrm{~F}$ activity was found in the main excretory organs.
Additionally, the uptake in the bone was low even at $120 \mathrm{~min}$, reflecting the good stability of the carbonfluorine bond. ${ }^{18} \mathrm{~F}$ activity accumulated in the liver with the highest value at $120 \mathrm{~min}$, indicating slow excretion and low metabolism. In all other organs studied, the ${ }^{18} \mathrm{~F}$ activity peaked 20 min after injection (see Table 3 ). The results from the in vivo study were in accordance with 
Table $3{ }^{18} \mathrm{~F}$-activity uptake after injection of $\left[{ }^{18} \mathrm{~F}\right] \mathrm{CFT}$ in the organs of control and pretreated rats

\begin{tabular}{|c|c|c|c|c|c|c|c|}
\hline Organ & $\begin{array}{c}10 \min \\
n=2\end{array}$ & $\begin{array}{c}20 \min \\
n=3\end{array}$ & $\begin{array}{c}40 \min \\
n=4\end{array}$ & $\begin{array}{c}120 \min \\
n=3\end{array}$ & $\begin{array}{c}\text { GBR12909 } \\
n=3\end{array}$ & $\begin{array}{c}\text { Nisoxetine } \\
n=3\end{array}$ & $\begin{array}{c}\text { Fluoxetine } \\
n=2\end{array}$ \\
\hline Blood & $0.06 \pm 0.03$ & $0.07 \pm 0.01$ & $0.05 \pm 0.02$ & $0.03 \pm 0.01$ & $0.04 \pm 0.01$ & $0.06 \pm 0.01$ & $0.03 \pm 0.02$ \\
\hline Liver & $0.65 \pm 0.45$ & $5.17 \pm 1.99$ & $4.90 \pm 3.74$ & $8.26 \pm 1.16$ & $3.38 \pm 0.94$ & $5.86 \pm 0.10$ & $4.22 \pm 1.22$ \\
\hline Adrenal gland & $0.28 \pm 0.14$ & $0.36 \pm 0.01$ & $0.24 \pm 0.03$ & $0.17 \pm 0.06$ & $0.23 \pm 0.07$ & $0.25 \pm 0.02$ & $0.24 \pm 0.11$ \\
\hline Spleen & $0.36 \pm 0.24$ & $0.88 \pm 0.28$ & $0.49 \pm 0.05$ & $0.26 \pm 0.13$ & $0.50 \pm 0.19$ & $0.44 \pm 0.07$ & $0.44 \pm 0.02$ \\
\hline Pancreas & $0.28 \pm 0.10$ & $0.53 \pm 0.04$ & $0.35 \pm 0.11$ & $0.16 \pm 0.01$ & $0.17 \pm 0.05^{*}$ & $0.31 \pm 0.02$ & $0.22 \pm 0.12$ \\
\hline Kidney & $0.72 \pm 0.16$ & $0.91 \pm 0.11$ & $0.66 \pm 0.31$ & $0.28 \pm 0.07$ & $0.53 \pm 0.13$ & $0.47 \pm 0.02$ & $0.41 \pm 0.18$ \\
\hline Stomach & $0.12 \pm 0.09$ & $0.53 \pm 0.38$ & $0.19 \pm 0.05$ & $0.08 \pm 0.05$ & $0.47 \pm 0.37$ & $0.11 \pm 0.01$ & 0.17 \\
\hline Lung & $0.51 \pm 0.37$ & $0.46 \pm 0.07$ & $0.29 \pm 0.08$ & $0.17 \pm 0.06$ & $0.20 \pm 0.05$ & $0.25 \pm 0.01$ & $0.25 \pm 0.04$ \\
\hline Heart & $0.14 \pm 0.06$ & $0.16 \pm 0.03$ & $0.11 \pm 0.02$ & $0.07 \pm 0.02$ & $0.10 \pm 0.03$ & $0.11 \pm 0.01$ & $0.13 \pm 0.02$ \\
\hline Muscle & $0.07 \pm 0.02$ & $0.15 \pm 0.03$ & $0.09 \pm 0.03$ & $0.05 \pm 0.01$ & $0.08 \pm 0.02$ & $0.10 \pm 0.01$ & $0.07 \pm 0.03$ \\
\hline Urinary bladder & $0.14 \pm 0.14$ & $0.51 \pm 0.23$ & $0.31 \pm 0.13$ & $0.24 \pm 0.13$ & $0.30 \pm 0.12$ & $0.28 \pm 0.01$ & $0.22 \pm 0.04$ \\
\hline Bone & $0.03 \pm 0.01$ & $0.09 \pm 0.02$ & $0.07 \pm 0.04$ & $0.19 \pm 0.15$ & $0.06 \pm 0.01$ & $0.31 \pm 0.20$ & $0.09 \pm 0.04$ \\
\hline Marrow & $0.22 \pm 0.16$ & $0.63 \pm 0.17$ & $0.47 \pm 0.10$ & $0.20 \pm 0.05$ & $0.39 \pm 0.12$ & $0.49 \pm 0.05$ & $0.40 \pm 0.04$ \\
\hline Fat, subcutaneous & $0.03 \pm 0.01$ & $0.06 \pm 0.01$ & $0.07 \pm 0.03$ & $0.03 \pm 0.01$ & $0.04 \pm 0.02$ & $0.07 \pm 0.01$ & $0.05 \pm 0.03$ \\
\hline
\end{tabular}

${ }^{*} p<0.05$ compared to $40 \mathrm{~min}$. Uptakes (percent injected dose per gram tissue) occurred in the organs of control rats at different time points and in organs of pretreated rats at $40 \mathrm{~min}$. All values are means \pm SD. The effect of pretreatment was compared with the uptake values of control rats at 40 min. Means were considered significantly different when $p<0.05$.

the ex vivo findings. $\left[{ }^{18} \mathrm{~F}\right] \mathrm{CFT}$ has been reported to be relatively resistant to metabolism; in a microdialysis study of 120 min in rodents, the amount of unmetabolized $\left[{ }^{18} \mathrm{~F}\right] \mathrm{CFT}$ was approximately $64 \%$ of the $\operatorname{total}^{18} \mathrm{~F}$ activity [31].

In the periphery, non-neuronal DAT expression and DAT immunoreactivity have been found in the stomach, pancreas, and kidneys [32]. $\left[{ }^{18} \mathrm{~F}\right] \mathrm{CFT}$ uptake in the pancreas, stomach, and kidneys was moderate in the present study. After GBR12909 pretreatment, the ${ }^{18}$ F-activity uptake decreased significantly in the pancreas, indicating DAT-specific binding. In this study, no NET- or SERTspecific binding of ${ }^{18} \mathrm{~F}$ activity was found in the periphery even though extraneuronal NET expression has been found in the lungs, adrenal medulla, and placenta [32].

In the brain, the accumulation of ${ }^{18} \mathrm{~F}$ activity in the striatum was specific for DAT; it was significantly decreased with GBR12909 pretreatment (Figure 4). In addition to DAT, the striatum contains a low density of SERT, and NET is virtually absent [33]. Neither fluoxetine nor

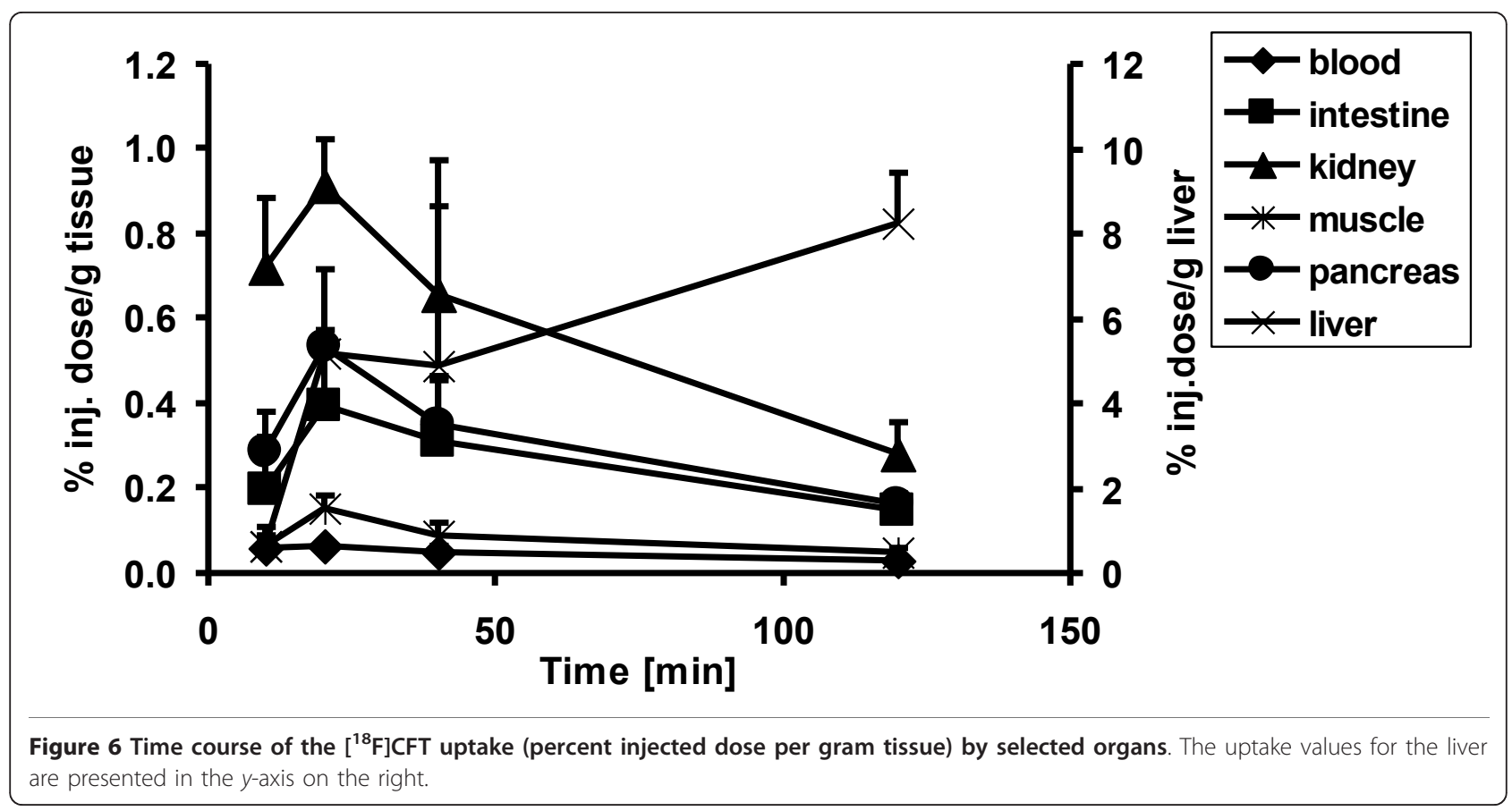




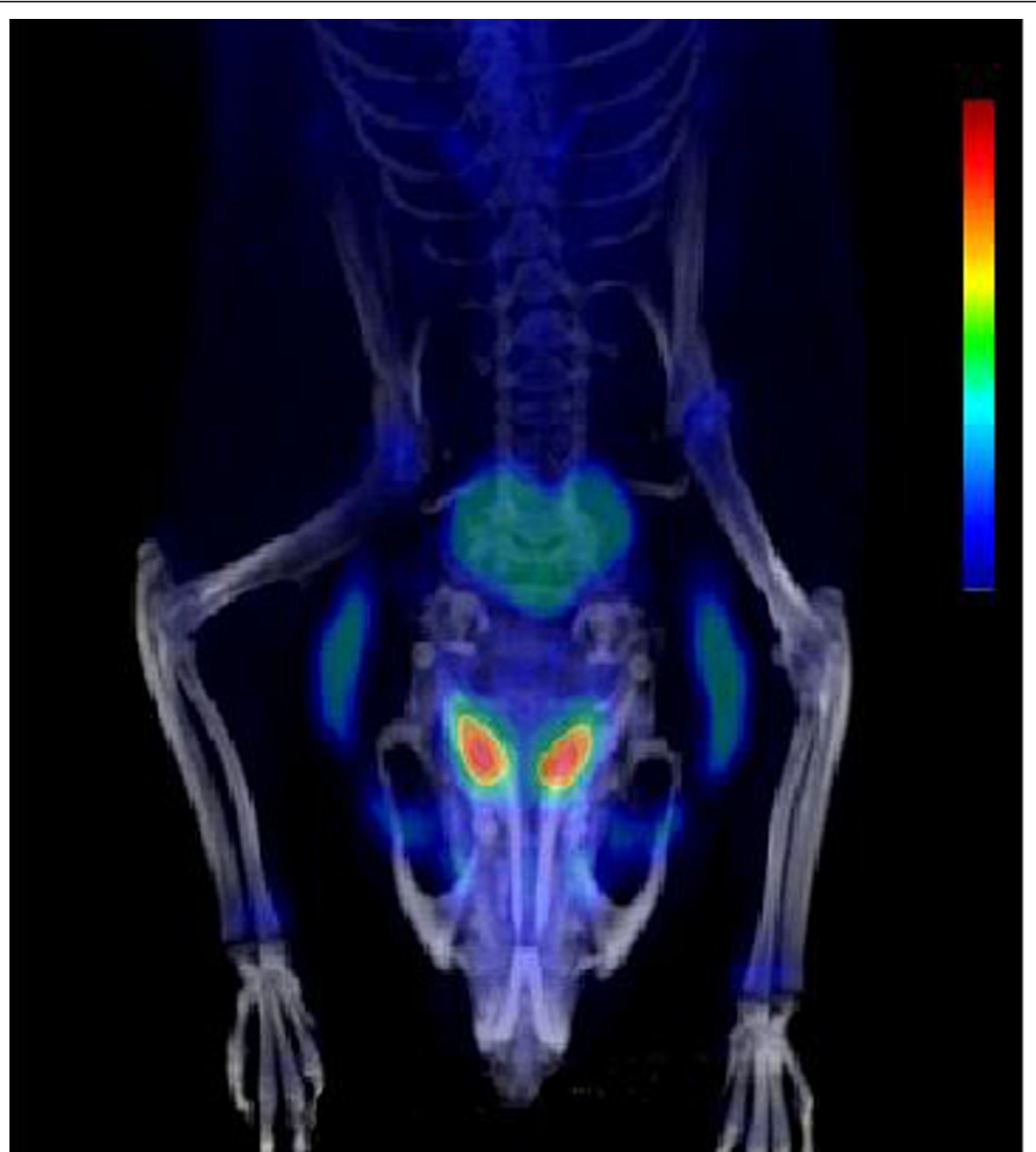

Figure 7 Animal PET-CT image of $\left[{ }^{18} \mathrm{~F}\right]$ CFT accumulation in the brain of rats. Data were collected for 2 to 120 min post injection.

nisoxetine pretreatment affected the ${ }^{18} \mathrm{~F}$-activity uptake in the striatum. High ${ }^{18} \mathrm{~F}$-activity accumulation was seen in the locus coeruleus, a brain region with high NET density as has been earlier shown by Burchett et al. [34]. A similar finding in monkeys using $\left[{ }^{3} \mathrm{H}\right]$ CFT was observed by Kaufman and Madras [19]. The ${ }^{18}$ F-activity accumulation in locus coeruleus was significantly decreased in rats pretreated with nisoxetine, which indicates that NET sites also bind with $\left[{ }^{18} \mathrm{~F}\right] \mathrm{CFT}$. Because NET is virtually absent in the striatum, $\left[{ }^{18} \mathrm{~F}\right] \mathrm{CFT}$ is suitable for imaging striatal DAT sites. However, the accumulation of ${ }^{18} \mathrm{~F}$ activity in locus coeruleus was also significantly decreased in rats pretreated with GBR12909. The affinity of CFT for DAT and NET is of the same order of magnitude (Table 1). With the relatively high dose of GBR12909 used in the pretreatment of the animals, it is evident that although the affinity of GBR12909 for NET is 50-fold less than for DAT, this dosage is high enough to displace $\left[{ }^{18} \mathrm{~F}\right] \mathrm{CFT}$ from the NET sites in the locus coeruleus. It is noteworthy that the $p$ value in the statistical analyses is higher for the locus coeruleus than for the striatum in the GBR12909 blocking study.

In the ex vivo study, the uptake ratios for the striatum, locus coeruleus, and cortex versus the cerebellum reached a maximum between 40 and $120 \mathrm{~min}$. In the in vivo study, the maximum striatum-to-cerebellum ratio was reached at $60 \mathrm{~min}$. In both studies, the absolute values for this ratio were similar in the range of 9 to 10 . It is noteworthy that due to its small size, the locus coeruleus cannot be analyzed from the in vivo PET study. These parallel studies provide a good demonstration of the strengths and weaknesses of different methods in radiopharmacological studies. Overall, the distribution of ${ }^{18} \mathrm{~F}$ activity in rats after $\left[{ }^{18} \mathrm{~F}\right] \mathrm{CFT}$ injection was in good agreement with our earlier preliminary studies $[5,8]$ and with studies using $\left[{ }^{3} \mathrm{H}\right] \mathrm{CFT}[19,35]$. 
The human ED and EDE values for $\left[{ }^{18} \mathrm{~F}\right] \mathrm{CFT}$ are $9.17 \mu \mathrm{Sv} / \mathrm{MBq}$ and $12.8 \mu \mathrm{Sv} / \mathrm{MBq}$, respectively, and they are in line with those of another dopamine transporter ligand ${ }^{18}$ F-FPCIT [36]. Extrapolation of the animal data to humans to estimate the human radiation dose is inexact, but the order of magnitude of the EDE and ED values for $\left[{ }^{18} \mathrm{~F}\right] \mathrm{CFT}$ correspond well with those of other ${ }^{18} \mathrm{~F}$-labeled radioligands.

\section{Conclusions}

Post-target-produced high-SA $\left[{ }^{18} \mathrm{~F}\right] \mathrm{F}_{2}$ was used to incorporate ${ }^{18} \mathrm{~F}$ directly into the phenyl ring of $\left[{ }^{18} \mathrm{~F}\right] \mathrm{CFT}$. The final product had high radiochemical and chemical purities and a high SA for neurotransmitter studies in vivo. It is noteworthy that as $\left[{ }^{18} \mathrm{~F}\right] \mathrm{CFT}$ shows a specific binding to NET in addition to DAT, $\left[{ }^{18} \mathrm{~F}\right] \mathrm{CFT}$ can also be used for imaging NET. The finding that $\left[{ }^{18} \mathrm{~F}\right] \mathrm{CFT}$ shows specific uptake in the pancreas also warrants future studies in humans with respect to potential utility in pancreatic imaging.

\section{Acknowledgements}

This work was supported by the Academy of Finland grant numbers 116084 and 128591 and by the Oskar Öflunds Stiftelse.

\section{Author details \\ ${ }^{1}$ Radiopharmaceutical Chemistry Laboratory, Turku PET Centre, University of Turku, Porthaninkatu 3, Turku, 20500, Finland ${ }^{2}$ MediCity/PET Preclinical Imaging, Turku PET Centre, University of Turku, Tykistökatu 6A, Turku, 20520, Finland ${ }^{3}$ Accelerator Laboratory, Åbo Akademi University, Porthaninkatu 3, Turku, 20500, Finland}

\section{Authors' contributions}

SF is the first author and has taken part in all aspects of preparing the manuscript. PM has contributed in the concept and design of the study, in acquiring preclinical data, and in analyzing and interpreting this set of data, as well as in drafting the manuscript. OE has contributed in the acquisition of radiochemical data and analyzing and interpreting this set of data, as well as in drafting the manuscript. JB has contributed in the concept and design of the study and has enhanced the intellectual content of the manuscript. $J R$ has contributed in acquiring the dosimetric data, in analyzing and interpreting this set of data, and in drafting the manuscript. TG has contributed in acquiring the preclinical data, in analyzing and interpreting this set of data, and in drafting the manuscript. MH has contributed in the concept and design of the study, in acquiring data, in analyzing and interpreting data, and in drafting the manuscript and has critically contributed to and revised the manuscript, as well as approved the final content of the manuscript. OS has contributed in the concept and design of the study, in analyzing and interpreting data, and in drafting the manuscript, as well as in approving the final content of the manuscript. All authors have read and approved the final manuscript.

\section{Competing interests}

The authors declare that they have no competing interests.

Received: 25 November 2011 Accepted: 25 January 2012 Published: 25 January 2012

\section{References}

1. Wong DF, Yung B, Dannals RF, Shaya EK, Ravert HT, Chen CA, Chan B, Folio T, Scheffel U, Ricaurte GA, Neumeyer JL, Wagner HN Jr, Kuhar MJ: In vivo imaging of baboon and human dopamine transporters by positron emission tomography using $\left[{ }^{11} \mathrm{C}\right]$ WIN 35,428. Synapse 1993, 15:130-142.
2. Stehouwer JS, Goodman MM: Fluorine-18 radiolabeled PET tracers for imaging monoamine transporters: dopamine, serotonin, and norepinephrine. PET Clin 2009, 4:101-128.

3. Schou M, Steiger C, Varrone A, Guilloteau D, Halldin C: Synthesis, radiolabeling and preliminary in vivo evaluation of $\left[{ }^{18} \mathrm{~F}\right] \mathrm{FE}-\mathrm{PE} 2 \mathrm{l}$, a new probe for the dopamine transporter. Bioorg Med Chem Lett 2009, 19:4843-4845.

4. Varrone A, Steiger C, Schou M, Takano A, Finnema SJ, Guilloteau D, Gulyás B, Halldin C: In vitro autoradiography and in vivo evaluation in cynomolgus monkey of $\left[{ }^{18} \mathrm{~F}\right] \mathrm{FE}-\mathrm{PE} 2 \mathrm{l}$, a new dopamine transporter PET radioligand. Synapse 2009, 10:871-880.

5. Haaparanta M, Bergman J, Laakso A, Hietala J, Solin O: $\left[{ }^{18} \mathrm{~F}\right] \mathrm{CFT}\left(\left[{ }^{18} \mathrm{~F}\right] \mathrm{WIN}\right.$ $35,428)$, a radioligand to study the dopamine transporter with PET: biodistribution in rats. Synapse 1996, 23:321-327.

6. Bergman J, Haaparanta M, Solin O: A novel radioisotope labelled compound, a mixture comprising said compound and a method for its preparation., Finnish Patent 96603, WO 96/20940.

7. Forsback S, Niemi R, Marjamäki P, Eskola O, Bergman J, Grönroos T, Haaparanta M, Haapalinna A, Rinne J, Solin O: Uptake of 6-[ $\left.{ }^{18} \mathrm{~F}\right]$ fluoro-Ldopa and $\left[{ }^{18} \mathrm{~F}\right] \mathrm{CFT}$ reflect nigral neuronal loss in a rat model of Parkinson's disease. Synapse 2004, 51:119-127.

8. Marjamäki P, Haaparanta M, Forsback S, Koivula T, Fagerholm V, Grönroos T, Eskola O, Solin O: Comparison of $2 \beta$-carbomethoxy-3 $\beta-\left(4-\left[{ }^{18} \mathrm{~F}\right]\right.$ fluorophenyl)tropane and $\mathrm{N}$-(3-[ $\left.{ }^{18} \mathrm{~F}\right]$ fluoropropyl)-2 $\beta$-carbomethoxy-3 $\beta$ (4- $\left[{ }^{18} \mathrm{~F}\right]$ fluorophenyl)nortropane, tracers for imaging dopamine transporters in rat. Mol Imaging Biol 2009, 12:269-277.

9. Laakso A, Bergman J, Haaparanta M, Vilkman H, Solin O, Hietala J: $\left[{ }^{18} \mathrm{~F}\right]$ CFT $\left[\left({ }^{18} \mathrm{~F}\right)\right.$ WIN 35,428$]$, a radioligand to study the dopamine transporter with PET: characterization in human subjects. Synapse 1998, 28:244-250.

10. Rinne JO, Bergman J, Ruottinen H, Haaparanta M, Eronen E, Oikonen V, Sonninen P, Solin O: Striatal uptake of a novel PET ligand, $\left[{ }^{18} \mathrm{~F}\right]$ beta-CFT, is reduced in early Parkinson's disease. Synapse 1999, 31:119-124.

11. Rinne JO, Ruottinen H, Bergman J, Haaparanta M, Sonninen P, Solin O: Usefulness of a dopamine transporter PET ligand $\left[{ }^{18} \mathrm{~F}\right]$ beta-CFT in assessing disability in Parkinson's disease. J Neurol Neurosurg Psychiatry 1999, 67:737-741.

12. Nurmi E, Ruottinen HM, Kaasinen V, Bergman J, Haaparanta M, Solin O, Rinne JO: Progression in Parkinson's disease: a positron emission tomography study with a dopamine transporter ligand $\left[{ }^{18} \mathrm{~F}\right] \mathrm{CFT}$. Ann Neurol 2000, 47:804-808.

13. Nurmi E, Bergman J, Eskola O, Solin O, Hinkka SM, Sonninen P, Rinne JO: Reproducibility and effect of levodopa on dopamine transporter function measurements: a $\left[{ }^{18}\right.$ F]CFT PET study. J Cereb Blood Flow Metab 2000, 20:1604-1609.

14. Rinne OJ, Nurmi E, Ruottinen HM, Bergman J, Eskola O, Solin O: $\left[{ }^{18}\right.$ F]FDOPA and $\left[{ }^{18} \mathrm{~F}\right] \mathrm{CFT}$ are both sensitive PET markers to detect presynaptic dopaminergic hypofunction in early Parkinson's disease. Synapse 2001, 40:193-200.

15. Nurmi E, Bergman J, Eskola O, Solin O, Vahlberg T, Sonninen P, Rinne JO: Progression of dopaminergic hypofunction in striatal subregions in Parkinson's disease using $\left[{ }^{18} \mathrm{~F}\right]$ CFT PET. Synapse 2003, 48:109-115.

16. Laakso A, Vilkman H, Alakare B, Haaparanta M, Bergman J, Solin O, Peurasaari J, Räkköläinen V, Syvälahti E, Hietala J: Striatal dopamine transporter binding in neuroleptic-naive patients with schizophrenia studied with positron emission tomography. Am J Psychiatry 2000, 157:269-271.

17. Laakso A, Bergman J, Haaparanta M, Vilkman H, Solin O, Syvälahti E, Hietala J: Decreased striatal dopamine transporter binding in vivo in chronic schizophrenia. Schizophr Res 2001, 52:115-120.

18. Laakso A, Vilkman H, Kajander J, Bergman J, Paranta M, Solin O, Hietala J: Prediction of detached personality in healthy subjects by low dopamine transporter binding. Am J Psychiatry 2000, 157:290-292.

19. Kaufman MJ, Madras BK: $\left[{ }^{3} \mathrm{H}\right] \mathrm{CFT}\left(\left[{ }^{3} \mathrm{H}\right]\right.$ WIN 35,428$)$ accumulation in dopamine regions of monkey brain: comparison of a mature and aged monkey. Brain Res 1993, 611:322-325.

20. Aloyo VJ, Ruffin JS, Pazdalski PS, Kirifides AL, Harvey JA: $\left[{ }^{3} \mathrm{H}\right]$ WIN 35,428 binding in the caudate nucleus of the rabbit: evidence for a single site on the dopamine transporter. J Pharmacol Exp Ther 1995, 273:435-444.

21. Koivula T, Marjamäki $P$, Haaparanta $M$, Fagerholm V, Grönroos T, Lipponen T, Perhola O, Vepsäläinen J, Solin O: Ex vivo evaluation of N-(3- 
$\left[{ }^{18} \mathrm{~F}\right]$ fluoropropyl)-2 beta-carbomethoxy-3 beta-(4-fluorophenyl) nortropane in rats. Nucl Med Biol 2008, 35:177-183.

22. Casella V, Ido T, Wolf AP, Fowler JS, MacGregor RR, Ruth TJ: Anhydrous F18 labeled elemental fluorine for radiopharmaceutical preparation. $J$ Nucl Med 1980, 21:750-757.

23. Chiracal R, Adams RM, Firnau G, Schrobilgen GJ, Coates G, Garnett ES: Electrophilic ${ }^{18} \mathrm{~F}$ from a Siemens $11 \mathrm{MeV}$ proton-only cyclotron. Nucl Med Biol 1995, 22:111-116.

24. Ruth TJ, Wolf AP: Absolute cross sections for the production of ${ }^{18} \mathrm{~F}$ via the ${ }^{18} \mathrm{O}(\mathrm{p}, \mathrm{n}){ }^{18} \mathrm{~F}$ reaction. Radiochemica Acta 1979, 26:21-24.

25. Bergman J, Solin O: Fluorine-18-labeled fluorine gas for synthesis of tracer molecules. Nucl Med Biol 1997, 24:677-684.

26. Stabin MG, Sparks RB, Crowe E: OLINDA/EXM: the second-generation personal computer software for internal dose assessment in nuclear medicine. J Nucl Med 2005, 46:1023-1027.

27. Paxinos G, Watson C: The Rat Brain in Stereotaxic Coordinates San Diego: Academic Press; 1986.

28. Kirschner A, Ice R, Beierwaltes W: Radiation dosimetry of 1311-19iodocholesterol: the pitfalls of using tissue concentration data, the author's reply. J Nucl Med 1975, 16:248-249.

29. Solin O, Eskola O, Hamill TG, Bergman J, Lehikoinen P, Grönroos T, Forsback S, Haaparanta M, Viljanen T, Ryan C, Gibson R, Kieczykowski G, Hietala J, Hargreaves R, Burns HD: Synthesis and characterization of a potent, selective, radiolabeled substance-P antagonist for NK1 receptor quantitation: ([ $\left.\left.{ }^{18} \mathrm{~F}\right] \mathrm{SPA}-\mathrm{RQ}\right)$. Mol Imaging Biol 2004, 6:373-384.

30. Annesley TM: Ion suppression in mass spectrometry. Clin Chem 2003, 49:1041-1044.

31. Haaparanta M, Grönroos T, Marjamäki P, Eskola O, Bergman J, Paul R, Solin O: In vivo sampling for pharmacokinetic studies in small experimental animals: a combination of microdialysis, planar chromatography and digital autoradiography. Mol Imaging Biol 2004, 6:27-33.

32. Eisenhofer $\mathrm{G}$ : The role of neuronal and extraneuronal plasma membrane transporters in the inactivation of peripheral catecholamines. Pharmacol Ther 2001, 91:35-62.

33. Hoffman BJ, Hansson SR, Mezey É, Palkovits M: Localization and dynamic regulation of biogenic amine transporters in the mammalian central nervous system. Front Neuroendocrinol 1998, 19:187-231.

34. Burchett S, Bannon M: Serotonin, dopamine and norepinephrine transporter mRNAs: heterogeneity of distribution and response to 'binge' cocaine administration. Mol Brain Res 1997, 49:95-102.

35. Scheffel U, Pögün S, Stathis M, Boja JW, Kuhar MJ: In vivo labeling of cocaine binding sites on dopamine transporters with $\left[{ }^{3} \mathrm{H}\right] \mathrm{WIN} 35,428$. Pharmacol Exp Ther 1991, 257:954-958.

36. Robeson W, Dhawan V, Belakhlef A, Ma Y, Pillai V, Chaly T, Margouleff C, Bjelke $\mathrm{D}$, Eidelberg D: Dosimetry of the dopamine transporter radioligand 18F-FPCIT in human subjects. J Nucl Med 2003, 44:961-966.

37. Singh S: Chemistry, design, and structure-activity relationship of cocaine antagonists. Chem Rev 2000, 100:925-1024.

38. Zhang $Y$, Joseph DB, Bowen WD, Flippen-Anderson JL, Dersch CM, Rothman RB, Jacobson AE, Rice KC: Synthesis and biological evaluation of tropane-like 1-[2-[bis(4-fluorophenyl)methoxy]ethyl]-4-(3-phenylpropyl) piperazine (GBR 12909) analogues. J Med Chem 2001, 44:3937-3945.

39. Tatsumi M, Groshan K, Blakely RD, Richelson E: Pharmacological profile of antidepressants and related compounds at human monoamine transporters. Eur J Pharmacol 1997, 340:249-258.

40. Walter MW: Monoamine reuptake inhibitors: highlights of recent research developments. Drug Dev Res 2005, 65:97-118.

doi:10.1186/2191-219X-2-3

Cite this article as: Forsback et al: $\left[{ }^{18} \mathrm{~F}\right] \mathrm{CFT}$ synthesis and binding to monoamine transporters in rats. EJNMMI Research 2012 2:3.

\section{Submit your manuscript to a SpringerOpen ${ }^{\circ}$ journal and benefit from:}

- Convenient online submission

- Rigorous peer review

- Immediate publication on acceptance

- Open access: articles freely available online

- High visibility within the field

- Retaining the copyright to your article

Submit your next manuscript at $>$ springeropen.com 